\title{
NEW DEVELOPMENT IN UNIVERSITY EXTRAMURAL WORK
}

\begin{abstract}
HE report of the Univorsities Council for Adult Education, 1961-62, entitled New Development in University Extramural Work*, prepared by Mr. A. Parker, director of Extramural Studies, University of Birmingham, is based on the reports of the extramural departments of the universities of the United Kingdom for 1961-62 and on additional information supplied by them. It raises again, at the outset, the question whether the new variety and extent of extramural work was entirely more opportunism, but Mr. Parker suggests that the past seven years have been formative and that a new pattern is emerging. $\mathrm{He}$ considers that diversity between the different forms of course that havo become established parts of extramural programmes-the day-release classes, the postgraduate courses, the provision for vocational groups, and work with industry-is less apparent than some years ago. Moreover, he feels that the underlying unity is to be sought in the distinctive kind of teaching that extramural departments should provide.

Sevoral departments have directed attention to an increasing tendency for extramural work to mirror the range of intramural work of universities, and this might provide a simple answer to the question as to the distinctive characteristics of extramural teaching. While Mr. Parker suggests that extramural departments may sometimes be able to make a special contribution to courses arranged in co-operation with university departments of technology, he suggests further that the traditional concorn of extramural departments with liberal studies has not diminished in importance. Howevor, it would seem that liberal studies are not necessarily promoted by the traditional means nor necessarily differentiated sharply from professional studies.

If it is accepted that extramural teaching should be of a distinctive kind, it should also follow that this teaching should be opon to all adults who aro capable of profiting from such teaching. The three-year tutorial class was designed to meet a particular need, and, despite the decline in the number of such classes, in many places it

* New Development in University Extramural Work. Report of the Universities Council for Adult Education: 1961-1962. Pp. 28. (Liverpool Hon. Secretary, Universities Council for Adult Education, The University,
1963.)
\end{abstract}

still exemplifies the best extramural teaching. It should be asked, however, whether the spirit of the tutorial class may be preserved in new forms of course designed to meet contemporary needs, and $\mathrm{Mr}$. Parker comments on the remarkable response at times in recent years from industrial workers, both in terms of quality and quantity.

Beyond this, Mr. Parker directs attention to the needs of a new group - the applicants with two or more Advanced-level General Certificate of Education subjectsfor whom university places cannot be found, and asks whether traditional policies towards providing extramural courses leading to examination should be revised. He recognizes that extramural courses could not provide a substitute for intramural courses, but points out that, if considered as an adjunct to some of the many proposals for meeting unsatisfied demand for university places, they could provide at least occasional contact between students and good university teachers. Curiously enough, even in this context, the possible contribution or purticipation of the colleges of technology does not appear to be visualized. Moreovor, while Mr. Parker recognizes that some extension of the principle of external degrees may be impliod, he does not consider what might be implied in the sug. gestion of a new kind of external degree examination, specially designed to test the particular abilities of mature students who have the advantages, as well as the disadvantages, of alternating study with employment.

The report also includes a section by $\mathrm{Mr}$. M. Bruce on the work of the Council's Sub-Committee on Broadcasting, set up in 1960, including its comments on the Government's White Paper on the Pilkington Report. The general expansion of programmes is welcomed, and educational programmes for adults are defined as programmes (othor than school broadcasts) arranged in sories and planned in consultation with appropriate educational bodies to help viewors towards the progressive mastery or undorstanding of some skill or body of knowledge. This definition is held to include programmes primarily designed for class use, for example, in technical colleges or centros for adult education, as well as thoso primarily designed for the viewer at home.

\section{THE C.S.I.R.O. ANIMAL RESEARCH LABORATORIES}

$\mathrm{T}$ HE annual report of the Commonwoalth Scientific and Industrial Research Organization Animal Rosearch Laboratories for 1961-62* continues the accounts of much important research work covering a wide variety of conditions and of groat importance to other countries. It outlinos the work of threo divisions dealing with animal genotics, animal health and animal physiology.

Apart from original work relating primarily to Australian conditions there are outstanding examplos of tho complementary value of work in Australia in the elucidation of important disease problems in many countries. Examples are the 'race', run off in 'heats' nearly half a century ago, on botulism research; the production of infective and toxic mixed culture after years of rosearch from cases of 'lamsiekte' in cattle in South Africa; the discovery that a similar disease of animals in A.ustralia was actually botulism; the triumph of technique in South

* C.S.I.R.O. Animal Research Laboratories. Annual Report 1961-1962. Pp. 177 (mimeographed). (Melbourne: Commonwealth Scientific and Industrial Research Organization, 1962.)
Africa that enabled pure cultures of the organism to be made; the finding that the basic causo of the condition in that country was deficiency of phosphorus in the soil that lod to depraved appetito with bone-chewing. The growth from this work of the importance of other mineral deficiencies that lead to ill-health in farm animals, Austra. lia taking a share in these developments, was a striking developmont of the decades prior to tho Second World War.

The importance of studies in general animal physiology was realized in certain of tho newer countries oarlier than in Britain, and, possibly with the less-entrenched and organized seats of loarning, such work bogan to receive rocognition in theso countrios at least a decado oarlier. With the incontive of utilizing the great areas of potontial animal country that is often of less obvious quality than tho animal production areas of the old world, plus an open-minded outlook towards such dovelopments, the enthusiasm and entorpriso shown has paid largo dividends. Work from Australia under the influence of the Commonwealth Scientific and Industrial Rosoarch Organization 